\title{
Characterization of A Raw Starch Degrading Alpha Amylase From The Rhizosphere Soil Citatah Karst Region Bacillus sp. $\mathrm{K}_{2} \mathrm{Br}_{5}$
}

\author{
Tina Dewi Rosahdi ${ }^{1}$, Tia Bestiana Nur Azizah ${ }^{2}$, Fitriani Nurul Hidayati ${ }^{3}$, \\ Rija Lailatus Syifa ${ }^{4}$, Risma Khoerunnisa ${ }^{5}$, Galih Lenggana ${ }^{6}$, Anggita Rahmi Hafsari ${ }^{7}$ \\ \{tina_dr@uinsgd.ac.id ${ }^{1}$ \} \\ Chemistry of Department, Faculty of Science and Technology, UIN Sunan Gunung Djati \\ Bandung $1,2,3,4,5,6$ \\ Biology of Department, Faculty of Science and Technology, UIN Sunan Gunung Djati Bandung?
}

\begin{abstract}
Amylase from Bacillus sp. $\mathrm{K}_{2} \mathrm{Br}_{5}$, a bacterium isolated from the Rhizosphere soil, Citatah Karst region, is partially purified by $60 \%$ ammonium sulfate precipitation. It displays optimum activity at $\mathrm{pH} 6.0$ and temperature $40{ }^{\circ} \mathrm{C}$. The presence of $\mathrm{Zn}^{2+}$ and $\mathrm{Ca}^{2+}$ metal ions increased the activity of $\alpha$-amylase, whereas $\mathrm{Cu}^{2+}, \mathrm{Na}^{+}$and $\mathrm{Mn}^{+}$metal ions and EDTA as chelating agent decreased the activity of $\alpha$-amylase. Futhermore, the addition of acarbose as inhibitor and $\mathrm{NaCl}$ decreased enzyme activity. $\alpha$-Amylase from Bacillus sp. $\mathrm{K}_{2} \mathrm{Br}_{5}$ showed ability to degrade wheat, rice, cassava, potato and corn starches with adsorption percentage in the range of $29-69 \%$. Wheat has the highest degree of hydrolysis followed by corn, rice, cassava and potato, consecutively at relative low temperatures. Meanwhile, rice has the highest adsorption percentage. The results show $\alpha$-amylase from Bacillus sp. $\mathrm{K}_{2} \mathrm{Br}_{5}$ is a good candidate for low temperature starch processing.
\end{abstract}

Keywords: $\alpha$-Amylase, Bacillus sp. $\mathrm{K}_{2} \mathrm{Br}_{5}$, raw starch.

\section{Introduction}

$\alpha$-Amylase is widely used in industrial processes including starch processing, textile industry, food and beverage processing industry to the pharmaceutical industry. $\alpha$-Amylase can hydrolyze $\alpha-1,4$-glycoside bonds inside the chain of amylose and amylopectin chain to produce smaller products such as glucose and dextrin [1]. $\alpha$-Amylase for industrial processes mainly derived from Bacillus genus are Bacillus licheniformis, Bacillus stearothermophilus and Bacillus amiloliquefaciens [2]. In the industrial processes, basic characteristics of $\alpha$-amylase such as $\mathrm{pH}$, temperature and buffer is needed for better application. Those properties contribute to the working system of enzyme because they directly related to the ion and the structure of the enzyme. The process of separation and purification also affect to the activity of produced enzyme.

The activity of $\alpha$-amylase affected by inhibitors such as concentration of salts, metal ions, and chelating agents. The results provided by Habibilah, I (2017) shows that the concentration of $\mathrm{NaCl}$ affect the activity of $\alpha$-amylase from Bacillus sp. $\mathrm{K}_{2} \mathrm{Br}_{5}$ [3]. The indicate that acarbose as inhibitor affects CcAmy and TcAmy to amylolytic activity [4]. The addition of metal ions 
$\mathrm{Cu}^{2+}, \mathrm{Na}^{+}$and $\mathrm{Mn}^{+}$increasing the activity of $\alpha$-amylase, and the addition of $\mathrm{Zn}^{2+}$ and $\mathrm{Ca}^{2+}$ decreases $\alpha$-amylase activity [5]. The addition of EDTA as chelating agent reduce the activity of $\alpha$-amylase [6].

Generally, three stages of starch hydrolysis are gelatinization, liquification and saccharification [7]. $\alpha$-Amylase with the ability to degrade raw starch has great demand because of its ability to hydrolyze raw starch without gelatinization process. Gelatinization is heating process over its gelatinization temperatur for each starches and reqire more energy. Therefore a raw starch enzyme can reduce the production cost of hydrolyzing starchy materials. Hydrolysis of raw starch is related to its ability to adsorb raw starch. The ability to adsorb raw starch represent an additional domain outside the active side of the enzyme that acts as a starch binding domain (SBD) [8]. SBD contribute to heterogenous reaction among $\alpha$-amylase and starch [22].

\section{Materials and Method}

\subsection{Microorganism and Raw Starch}

Bacillus sp. $\mathrm{K}_{2} \mathrm{Br}_{5}$ isolated from Karst soil region Citatah Bandung by Maulani and obtained from Laboratory of Genetica and Molecular Departmen of Biology UIN Bandung [9]. Commercial grade regular potato, corn, cassava, rice and wheat starch was purchased from local supermarkets in Bandung, West Java Indonesia.

\subsection{Bacterial Screening/ Qualitative tests of $\alpha$-amylase activity}

The bacteria were grown on Nutrient agar plates (NA: $0.5 \% \mathrm{w} / \mathrm{v}$ of peptone, $0.3 \% \mathrm{w} / \mathrm{v}$ of yeast extract, and $1.5 \% \mathrm{w} / \mathrm{v}$ agar in $0.5 \% \mathrm{v} / \mathrm{v} \mathrm{NaCl}$ and Aquadest) containing $1 \%(\mathrm{w} / \mathrm{v})$ of soluble starch. After inoculating the culture at $35^{\circ} \mathrm{C}$ for $18 \mathrm{~h}$, iodine solution $(0.5 \% \mathrm{w} / \mathrm{v} \mathrm{KI}$ and $0.15 \% \mathrm{w} / \mathrm{v}$ ) was added to the culture containing $1 \% \mathrm{w} / \mathrm{v}$ of starch [10]. The bacteria that has $\alpha-$ amylolytic activity were screened and indicated the ability to degrade raw starch.

\section{$2.3 \alpha$-Amilase separation}

$\alpha$-Amylase from Bacillus sp. $\mathrm{K} 2 \mathrm{Br} 5$ was grown in $100 \mathrm{~mL}$ TSB on a rotary shaker (150 $\mathrm{rpm}$ ) for $24 \mathrm{~h}$ at $35^{\circ} \mathrm{C}$. Cells were removed by centrifugation ( $4000 \mathrm{rpm}, 15 \mathrm{~min}$ ) [4]. Crude extract or supernatant total protein content determined [11] and precipitated with $60-80 \%$ saturated ammonium sulfate. This ammonium sulfate fraction was used for further studies. The precipitate was dialyzed against various buffer sodium phosphate, potassium phosphate, phosphate-citrate buffer ( $\mathrm{pH} 7.0$ ). Dialysis process carried out at $4^{\circ} \mathrm{C}$ and buffer replacement was ended every 1 hour for 4 hours [10].

\subsection{Determination of $\alpha$-amylase activity}

a-Amylolytic activity was determined by measuring the amount of reducing sugars formed using a modification of the dinitrosalicylic acid (DNS) method with glucose as the calibration standard. Amylase assay was performed for $10 \mathrm{~min}$ in a $50 \mu \mathrm{L}$ reaction mixture which consisted of $25 \mu \mathrm{L}$ of $1 \%$ soluble starch and $25 \mu \mathrm{L}$ of suitably diluted enzyme in $50 \mathrm{mM}$ sodium phosphate buffer $\mathrm{pH} 6$ at $40^{\circ} \mathrm{C}$. The activity was stopped by addition of $50 \mu \mathrm{L}$ DNS solution $(1 \% \mathrm{w} / \mathrm{v}$ 
DNS, 0.4 M NaOH, and 30\% w/v K-Na-tartrat). The reaction mixture was then incubated in a boiling water bath for $10 \mathrm{~min}$ [13]. Subsequently, the reaction mixture was cooled down until reach room temperature and aqua $\mathrm{DM}$ added into the reaction mixture to total volume $1 \mathrm{~mL}$ before the absorbance at $500 \mathrm{~nm}$ was measured. All assays were conducted in triplicates.

\subsection{Determination total protein content}

Total protein concentration determined using the Bradford method, by adding $500 \mu \mathrm{L}$ Bradford reagent to $500 \mu \mathrm{L}$ of enzyme solution then absorbance is measured at $\lambda 595 \mathrm{~nm}$ [12]. BSA (Bovine Serum Albumin) used as calibration standard.

\subsection{Effect of pH and temperature on $\alpha$-amylolytic activity}

The effect of $\mathrm{pH}$ and temperature to $\alpha$-amilase activity determined by universal buffers (succinic acid, $\mathrm{NaH}_{2} \mathrm{PO}_{4}$, glycine) at $\mathrm{pH}$ 4-10. The optimum temperature determined in range $30-90^{\circ} \mathrm{C}$ using the obtained optimum $\mathrm{pH}$. The effect of buffers as starch solvents on enzyme activity determined using various buffer, sodium phosphate, phosphate citrate and potassium phosphate buffer using obtained optimum $\mathrm{pH}$ and temperature [14].

\subsection{Effect of salt, acarbose, chelating agent and metal ions to $\alpha$-amylolytic activity}

The effect of salt, acarbose and EDTA concentration on $\alpha$-amylase activity determined using various concentrations of $\mathrm{NaCl}$ from 0.005 to $0.1 \mathrm{M}$; acarbose from 0.00025 to $0.002 \mathrm{M}$ and EDTA from 1 to $20 \mathrm{mM}$. The effect of metal ion on $\alpha$-amylase activity determined using $\mathrm{Ca}^{2+}, \mathrm{Cu}^{2+}, \mathrm{Zn}^{2+}, \mathrm{Mn}^{2+}$ and $\mathrm{Na}^{+}$concentration $5 \mathrm{mM}$. The mixture incubated at room temperature for 1 hour before the activity of $\alpha$-amylase determined.

\subsection{Determination of raw starch adsorbability and digestibility}

The affinity of $\alpha$-amylase to starch determined by incubating $20 \mathrm{mg}$ of raw starch with 0.5 $\mathrm{mL}$ of an enzyme at $4^{\circ} \mathrm{C}$ for 1 hour, then centrifuged at $4000 \mathrm{rpm}$ for 15 minutes. The activity of residual $\alpha$-amylase determined using the same procedure. The adsorption percentage calculated with the equation $\%$ Ads $=[(\mathrm{B}-\mathrm{A}) / \mathrm{B}] \times 100$. A shows the activity of residual $\alpha-$ amylase, B shows enzyme activity in dissolved starch [13].

Identification of the ability of $\alpha$-amylase to hydrolyze raw starch determined by incubating $0.15 \mathrm{~mL}$ of $1 \% \mathrm{~b} / \mathrm{v}$ starch-enzyme solution with $0.5 \mathrm{~mL}$ phosphate buffer $50 \mathrm{mM} \mathrm{pH} 6$, each at $40^{\circ} \mathrm{C}$ and room temperature for $24 \mathrm{~h}$. The reaction mixture centrifuged at $4000 \mathrm{rpm}$ for 15 minutes [10]. \% DH determined by adding $0.05 \mathrm{~mL}$ DNS reagent to $0.05 \mathrm{~mL}$ supernatant and is put into boiling water for 10 minutes. The reaction mixture stored at room temperature and aqua DM is added to total volume of $1 \mathrm{ml}$. The absorbance measured at $500 \mathrm{~nm}$. Degree of hydrolysis $(\mathrm{DH})$ defined using $\% \mathrm{DH}=\left(\mathrm{H}_{1} / \mathrm{H}_{0}\right) \times 100 . \mathrm{H}_{1}$ for reducing sugars from hydrolysis by enzymes and $\mathrm{H}_{0}$ for reducing sugars from hydrolysis by acids. Acid hydrolysis carried out by incubating $20 \mathrm{mg}$ of raw starch with $0.2 \mathrm{~mL}$ of $1 \mathrm{M} \mathrm{HCl}$ at $100^{\circ} \mathrm{C}$ for $2 \mathrm{~h}$ and reducing sugar content measured with the same procedure [13].

\subsection{Characterization : Scanning Electron Microscopy}

$150 \mu \mathrm{L}$ mixture of $1 \% \mathrm{w} / \mathrm{v}$ of various type of raw starch (potato, wheat, corn, cassava, and rice) of amylase added to final volume $0.2 \mathrm{~mL}$ of $50 \mathrm{mM}$ phosphate citrate buffer $\mathrm{pH} 6$ and was incubated at $40^{\circ} \mathrm{C}$ for $24 \mathrm{~h}$. After centrifugation, the pellet was washed with $95 \%$ ethanol then 
dried at $35^{\circ} \mathrm{C}$. The treated starch granules were coated with Pt-Pd using Ion Sputter at $1.2 \mathrm{KV}$ and $6 \mathrm{~mA}$ for $4 \mathrm{~min}$. The hydrolyzed starches photographed using SEM (JSM-36510).

\section{Results and Discusion}

The bacteria isolates were screened for their activity to degrade raw starch. The clear zone or halozone in the solid media (Figure 1) indicates activity of $\alpha$-amylase produced by Bacillus sp. K2Br5 hydrolyzing the starch in the media around the colonies. The blackish-blue color outside the clear zone indicates the starch that has not been hydrolyzed.

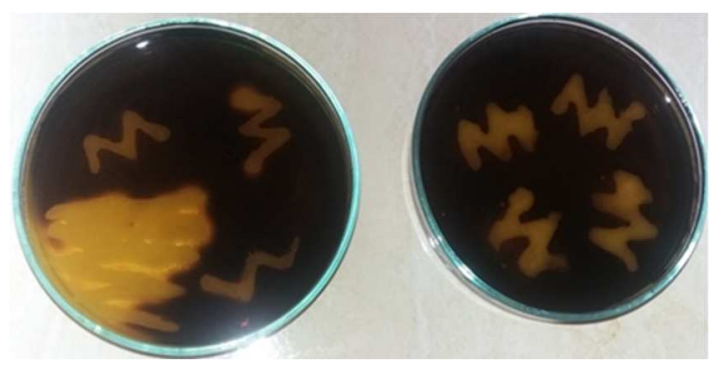

Figure 1. Qualitative tests of $\alpha$-amylase

The activity of crude extract $\alpha$-amylase is $2,632 \mathrm{U} / \mathrm{mg}$ and increase after fractionation and dialysis processes with the highest specific activity $6,982 \mathrm{U} / \mathrm{mg}$ at $60 \%$ fraction (Figure 2 ). $60 \%$ ammonium sulfate is the optimum fraction for $\alpha$-amylase separation because the enzyme participate more than other fractions. Potassium phosphate is the optimum dialysis bufer because potassium has higher electronegativity than sodium.

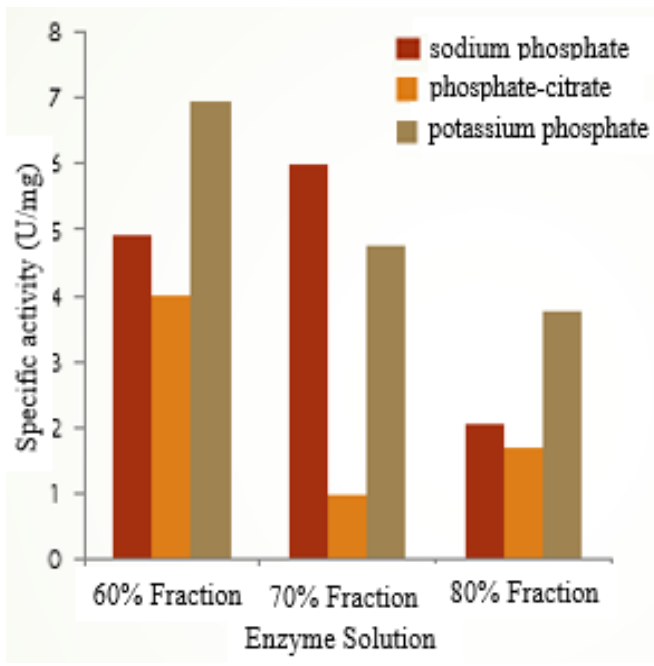

Figure 2. Optimum fractionation and dialysis 
The optimum $\mathrm{pH}$ of $\alpha$-amylase is $\mathrm{pH} 6$, the obvious increase activity at $\mathrm{pH} 4-5$ and gradually decreases at $\mathrm{pH} 7-10$, therefore $\alpha$-amylase activity from Bacillus $\mathrm{sp} . \mathrm{K}_{2} \mathrm{Br}_{5}$ worked optimally at $\mathrm{pH} 6$ (figure 3). At optimum $\mathrm{pH}$, the number of $\mathrm{H}^{+}$ion does not affect the enzyme conformation and remain same as the substrate conformation. This interaction between enzymes and substrate increased the activity and reached the highest at $6.011 \mathrm{U} / \mathrm{mg}$. Similar results obtained by Jai Shankar Paul (2016) for Bacillus sp. MB6 [14].

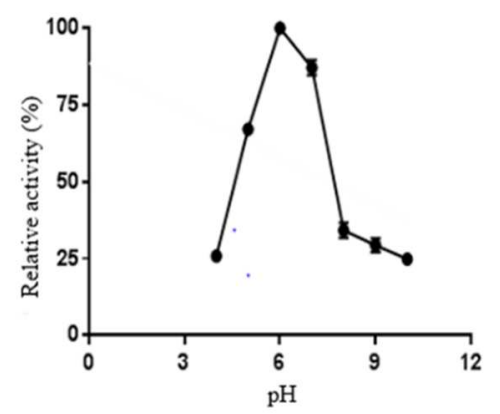

$\mathbf{a}$

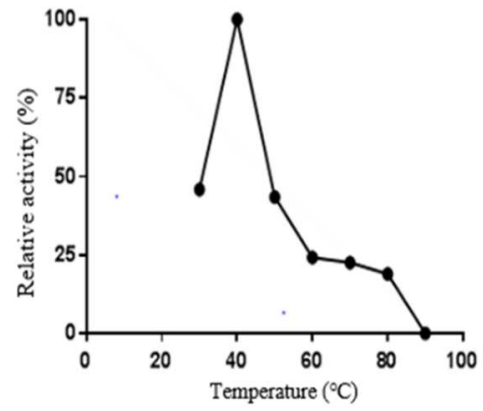

b

Figure 3 Optimum pH (a), Optimum temperature (b)

The optimum temperature of $\alpha$-amylase is $40^{\circ} \mathrm{C}$, the obvious increase in activity at $30^{\circ} \mathrm{C}$, gradually decreased at $50^{\circ} \mathrm{C}$ to $80^{\circ} \mathrm{C}$ and denaturated at $90^{\circ} \mathrm{C}$ (Figure 4). At the optimum temperature the activation energy required for a molecule to vibrate and made the enzyme work optimally to have higher specific activity $8,403 \mathrm{U} / \mathrm{mg}$ [23]. Similar results by Rasooli et al., (2008) for Bacillus subtilis [15].

The optimum buffer is $50 \mathrm{mM}$ phosphate citrate buffer $\mathrm{pH} 6$ (Figure 5). Enzyme activity obviously increase after the characteristics of $\mathrm{pH}$, temperature and solvent buffer starch obtained. In the optimum buffer, the reaction between buffer ions and the substrate has no significant effect, the optimum activity is $8,982 \mathrm{U} / \mathrm{mg}$. Similar results also obtained by Fitriani on Bacillus subtilis [16].

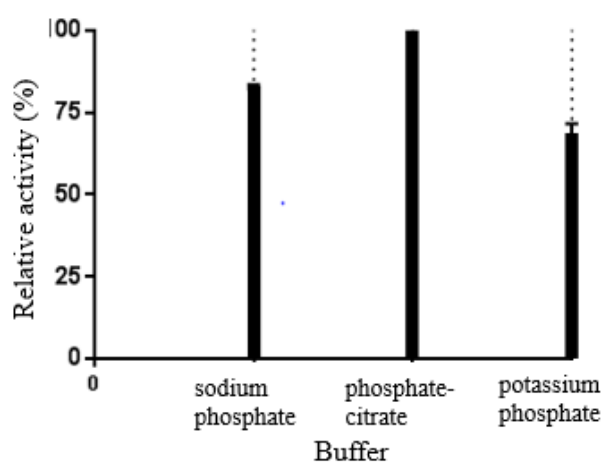

Figure 4. Effect of Bufer 
Acarbose decreasing the activity of $\alpha$-amylase as the concentration increased (Figure 6). Decreasing activity of $\alpha$-amylase by acarbose reveal attachment to carbohydrate-binding sites have higher affinity than normal substrate [17]. Because of the presence of intramolecular nitrogen, as long as $\alpha$-amylase binds to the acarbose, the incoming substrat cannot be digested and glucose cannot be released. The enzymatic bond stops because the $\mathrm{C}-\mathrm{N}$ bond in the acarviosine unit of the acarbose cannot be broken [18].

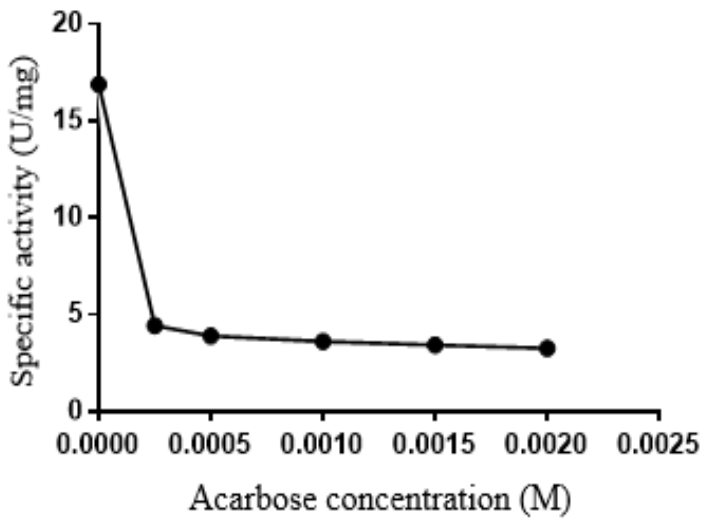

Figure 5. Effect of acarbose consentration

At the highest concentration of salt added, $\alpha$-amylase has no activity (Figure 7). Higher salt concentration increase the amount of ions in solution. These ions disrupt the electrostatic interactions between amino acids that hold the tertiary structure within enzyme structure [19]. While protein folding is necessary for the function of the enzyme, this can render the enzyme nonfunctional, or denature the enzyme [23].

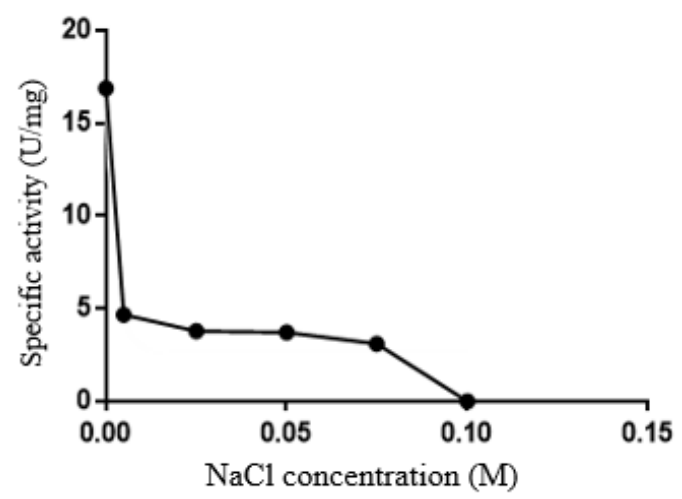

Figure 6. Effect of $\mathrm{NaCl}$ consentration 
The addition of chelating agent EDTA decrease $\alpha$-amylase activity as the concentration higher (Figure 8). EDTA as metaloenzyme binds metal ion in the structure of $\alpha$-amylase and inhibit the enzyme activity. The same result showed by Xie [1].

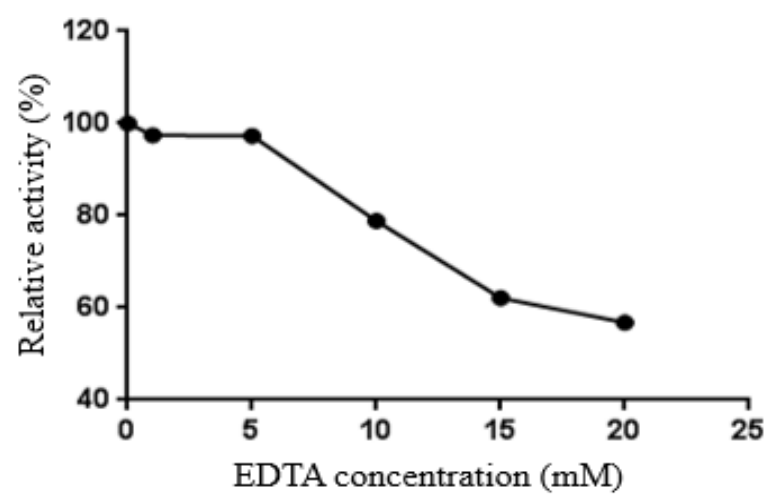

Figure 7. Effect of EDTA consentration

The effect of metal ions characterization shows both increasing and decreasing enzyme activity. $\mathrm{Cu}^{2+}, \mathrm{Mn}^{2+}$ and $\mathrm{Na}^{+}$metal ion reduce $\alpha$-amylase activity, while $\mathrm{Zn}^{2+}$ and $\mathrm{Ca}^{2+}$ increase $\alpha$-amylase activity (Figure 9). $\mathrm{Ca}^{2+}$ acts as an activator and the same result from Sudaryati revealed the addition of $\mathrm{Ca}^{2+}$ increase enzyme activity and maintain the activity of the enzyme [18] because of its metalloenzyme property [19]. $\mathrm{Zn}^{2+}$ act as an activator, but is unable to maintain the stability of enzyme activity. Other metal ions act as an inhibitor for reducing enzyme activity [4].

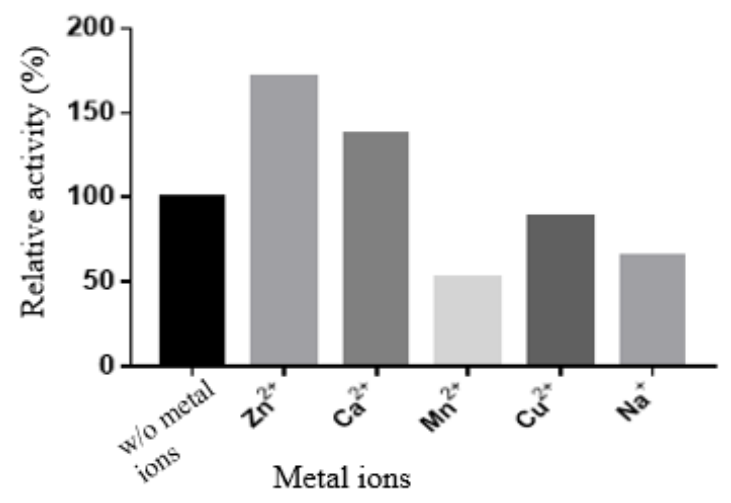

Figure 8. Effect of metal ions

Substrate identification reveals $\alpha$-amylase from Bacillus sp. $\mathrm{K}_{2} \mathrm{Br}_{5}$ has the ability to degrade and adsorb raw starch. The characterization show rice starch has the smallest granule size with the highest adsorption per cent $68.92 \%$, while the size of potato starch is bigger granule size showed the lowest percentage of adsorption 29.08\% (Figure 10). 


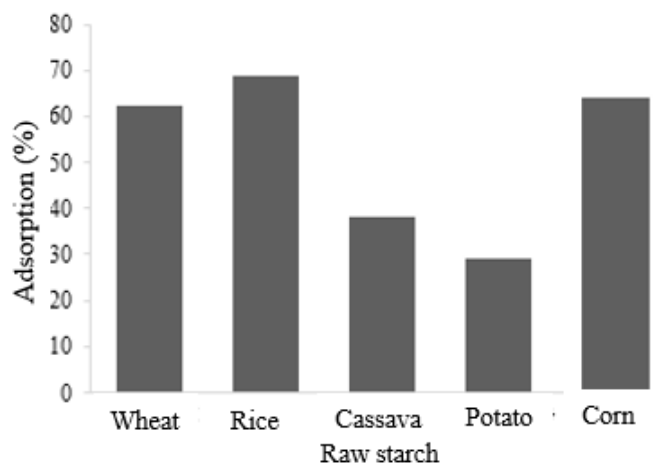

Figure 9. Raw starch adsorption (\%)

Amylase from Bacillus sp. isolates. K2Br5 has the ability to degrade raw starch with a tendency to hydrolyze cereal starch. The highest degree of hydrolysis in wheat starch with incubation temperature $40^{\circ} \mathrm{C}$ for 24 hours is $79.882 \%$ while the lowest at potato starch at $51.707 \%$ with incubation temperature $27^{\circ} \mathrm{C}$ for 24 hours (Figure 11).

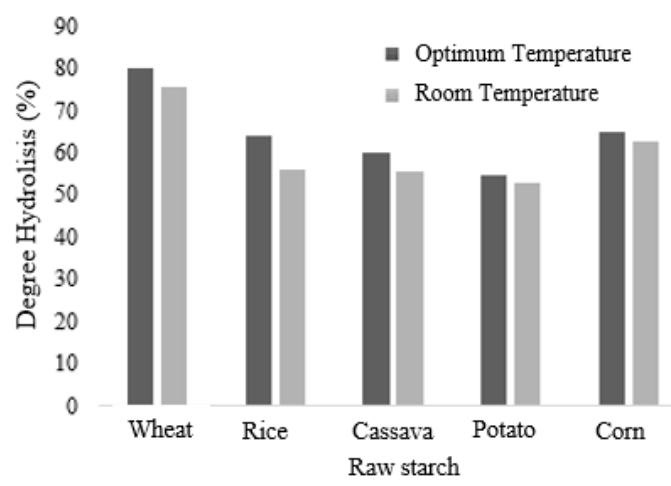

Figure 10. Degree of Hydrolisis (\%)

The SEM characterization shows the breakdown pattern of $\alpha$-amylase by relatively forming holes or pores on the surface of cereal starches and peeling the surface of tubers starch (Figure 12). Wheat starch granules looked more damaged among other cereal starch, it has few big pores and peeled on the surface, while other cereal starch each, rice and corn, has few big pores and relatively smaller pores. Although hardly hydrolyzed, tuber starch, cassava and potato, show peeled pattern on a surface. 

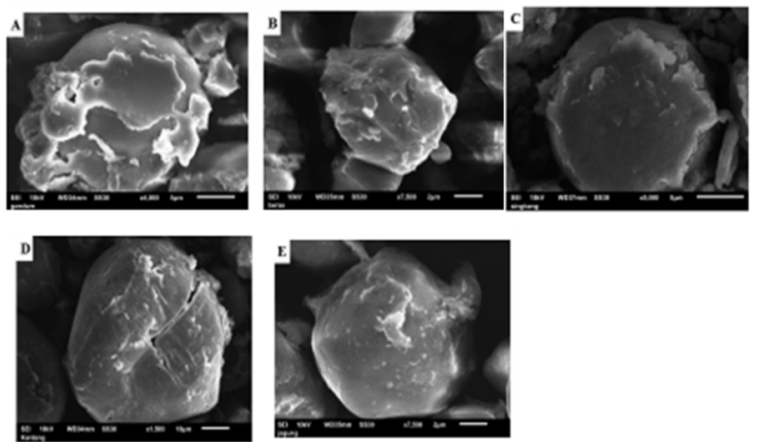

Figure 11. SEM Characterization after hydrolysis of raw starch a) wheat b) rice c) cassava d) potatoes e) corn

\section{Discussion}

The partially purified $\alpha$-amylase from Bacillus sp. K2Br5 displayed optimum activity at $\mathrm{pH} 6$ and $40^{\circ} \mathrm{C}$ using phospate citarate buffer. The raw starch degestibility revealed different pattern of hydrolized raw starch depends on the characterization of each type-A and B-type starch [7]. The highest \% DH in wheat starch showed two degrade patterns, peel and form holes in the starch surface. The type-B cereal starches have hexanogal structures that form spaces, therefore they have more structured water molecules. Otherwise, the A-type starch growth ring has a thicker structure, indicating that the amylopectin chain is relatively longer and complex than type B, these indicate type-A starch is more resistant to enzyme attacks [7]. The same results revealed by Puspasari's research). Nurachman, Z et al (2010) and Shinsaku, H (1988) using the same genus Bacillus $s p$. from marine culture, tropical sea and soil [13] [20] [21]. Although the same result shown in the pattern of hydrolysis, there are several differences in homogenity, the number and depth of holes or pores for each starch.

Partially purified $\alpha$-Amylase from Bacillus sp. $\mathrm{K} 2 \mathrm{Br} 5$ has the ability to adsorb raw starch. The enzyme has highest affinity toward starch granules of rice. Factors that contribute to starch adsorption are the size and starch granule shape. The larger starch grain, the lower the ratio of surface area [13], the consequence is enzyme has lower interactions with starch grains. Rice starch has the smallest granule size $2 \mu \mathrm{m}$ and potato has the largset granule size among other starch $10 \mu \mathrm{m}$. In addition, the form of starch granules which vary from very round to polyhedral made a different factor in adsorption percentage. The more rounded shape of the starch grain, the smaller the ratio of surface area and the closer to polyhedral shape has a greater surface rasio area [13]. The result showed potato starch has more rounded and big granule among other starch However, the observations show the size or dimensional effect of starch grains has a more dominant relation to the affinity of adsorption than the form of starch grain.

Signify 2 raw starch degrading enzyme, enzymes that can hydrolyze and adsorb raw starch and enzymes that can hydrolyze raw starch but cannot adsorb raw starch [24]. The ability to adsorb raw starch represents the possibility of SBD in the protein structure. According to Rodriguez, one of the roles of SBD in the structure of $\alpha$-amylase is to form interactions between insoluble substrates and enzymes in solution or heterogenic interaction. The function is to facilitate the transfer of starch to the active site of the enzyme in the catalytic domain [22]. Further analysis is needed to determine the structure, type and location of SBD. The characterization of substrate specificity showed no direct correlation between the ability of hydrolysis and raw starch adsorption. Although the ability to adsorb starch can increase the 
speed of raw starch hydrolysis due to the presence of SBD in non-catalitic domain, the binding process of starch granules by SBD depends more to the size of starch granules whilts high percentage of hydrolysis affected by the characteristics of type-A and type-B starch and the presence of active site in catalitic domain.

\section{Conclussion}

$\alpha$-Amylase from Bacillus sp. $\mathrm{K}_{2} \mathrm{Br}_{5}$ is a good enzyme candidate for low temperature starch processing with the tendency to cereal starch.

\section{References}

[1] F, Xie, S. Quan and D. Liu, 'Purification and characterization of a novel $\alpha$-amylase from a newly isolated Bacillus methylotrophicus strain P11-2,' Process Biochemistry, vol. 49, no. 1, pp. 47-53," 2014.

[2] C, D. Mathew and S. Rathnayake, 'Isolation and characterization of alpha amylase isolated from a hot water spring in Sri Lanka,' International research journal of microbiology, vol. 5, no. 4, pp.," pp. 50-61, 2014.

[3] I, Habibillah, 'Pengaruh Ion Logam, $\mathrm{NaCl}$ dan EDTA terhadap Aktivitas Alfa amilase dari Bacillus sp. K2Br5,' Bandung,” 2018.

[4] C. M, .M, Sonal; A. J, Bhide; Yashpal, Yadav;, "Characterization of Two Coleopteran $\alpha$ amylase and Molecular Insight into their Differential Inhibition by Synthetic $\alpha$ amylase Inhibitor,Acarbose,' Insect Biochemistry and Molecular Biology, vol. 74,” pp. 1-11, 2016.

[5] A, .Kangpienjai, S. Lumyong, T. Nguyen and H. D., "'Characterization of A Maltose forming $\alpha$-amylase from an amylolytic lactic acid bacterium lactobacillus plantarum,' Journal of milecular of catalysis B. Enzymatic, vol. 2,” pp. 1-8.

[6] P., Lestari, N. Richana and A. Darwis, 'Purifikasi dan karakterisasi a-amilase termostabil dari Bacillus stearothermophilus TII-12,' Jurnal Agrobiogen,” pp. 56-62, 2011.

[7] F. J, Robyt, "Essentials of Carbohydrate Chemistry, Boston USA: Springer Media New York," 1997.

[8] S, Janecek and J. Sevcik, "The Evolution of Starch-Binding Domain, Slovakia: Institute of Microbiology, Slovak Academy of Sciences," 1999.

[9] M. S, Maulani, 'Isolasi dan Identifikasi Bakteri pada Tanah Rhizosper di Kawasan Karst Citatah Kabupaten Bandung Barat serta Aplikasinya pada Perkecambahan Tanaman Cabai Merah (Capsicum annuum L.),' UIN Sunan Gunung Djati, Bandung,” 2015.

[10] E., Nuraliyah, 'Isolasi dan karakterisasi alfa amylase dari bacillus sp K2Br5,' UIN Sunan Gunung Djati , Bandung," 2017.

[11] A. C, Afiukwa, 'Determination of amylase activity of crude extract from partially germinated mango seeds (mangifera oraphila),' African journal of Biotechnology, vol. 8, no. 14," pp. 3294-3296, 2009.

[12] B. M, Bradford, 'A rapid and sensitive method for the quantitation microorganism quantities of protein utilizing the principle of protein-dye binding,' Journal Biochem, vol. 72, pp. 248- 
$254, " 1976$

[13] P. F, Puspasari, Z. Nurachman and A. A. S. Noer, "Characteristics of raw starch degrading aamylase from Bacillus aquimaris MKSC 6.2 associated with soft coral Sinularia sp,' Starch/starcke, vol. 63," pp. 461-647, 2011.

[14] B. L. and S. J. J. Paul, "Parameter's optimization and kinetics study of $\alpha$-amylase enzyme of Bacillus sp. MB6 isolated from vegetable waste,' Process Biochemistry, vol. 52," pp. 123 129, 2017.

[15] I. Rasooli, D. Shakiba and H. Borna, "A Thermostable $\alpha$-Amylase Producing Natural Variant of Bacillus s pp . Isolated From Soil in Iran,' American Journal of Agricultural and Biological Sciences, vol. 3, no. 3," pp. 591-596, 2008.

[16] Fitriani, A. and F. Supriyanti, 'Penentuan Aktivitas Amilase Kasar Termofil Bacillus subtilis Isolat Kawah Gunung Darajat Garut,' Bionatura-Jurnal Ilmu-ilmu Hayati dan Fisik, vol. 15, no. 2,"pp. 107-113, 2013.

[17] A. Krentz, and C. Bailey, 'Oral Antidiabetic Agents: Current Role in Type 2 Diabestes,' vol. 3, no. 65," pp. 223-241, 2005.

[18] Y. Sudayarti, “Kemampuan Bacillus licheniformis dalam Menghasilkan Enzim Alfa Amilase,"” pp. 1162-1166, 2015.

[19] P. Hayati, and T. Marbun, " Reservasi Xilanase Bacillus pumilus PU4-2 dengan teknik imobilisasi pada Pollard dan penambahan Kation,"” pp. 63-71, 2010.

[20] Z. Nurrachman, A. Kono and O. Karna, 'Identification a Novel Raw-Starch-Degrading- $\alpha$ Amylase from a Tropical Marine Bacterium,' American Journal of Biochemistry and Biotechnology, vol. 4,” pp. 300-306, 2010.

[21] S. Hayashida, Y. Teramoto and T. Inoue, 'Production and Characteristics of Raw-PotatoStarch-Digesting o-Amylase from Bacillus subtilis 65,' Applied and Environmental Microbiology, vol. 54, no. 6, pp. 1516-1522," 1998.

[22] R. Rodri' guez, N. Oviedo and S. Sanchez, 'Microbial Starch-Binding Domain,' Ecology and industrial microbiology, vol. 8," pp. 260-267, 2005.

[23] E. Dawood, S. Ibrahim and S. El-Nagerabi, 'Some properties of thermostable Alpha amylase of four isolates of bacillus licheniformis,' Nusantara Bioscience, vol. 40," pp. 2291-2296, 2005 .

[24] L. M. Hamilton, C. T. Kelly dan W. M. Fogarty, 'Production and properties of the raw starch digesting a-amylase of Bacillus sp. IMD 435,' Process Biochemistry, vol. 35,” pp. 27-31, 1999. 